\title{
THE SLOVENIAN ART HISTORY TEXTBOOK IN COMPARISON TO POLISH TEXTBOOKS: AUTHORSHIP AND CONTENT, DIDACTIC STRUCTURE AND PUBLISHING CIRCUMSTANCES
}

\author{
MARJANA DOLŠINA \\ Faculty of Arts, University of Ljubljana, \\ Aškerčeva cesta 2, Ljubljana, Slovenia \\ E-mail adress: marjana.dolsina@gmail.com
}

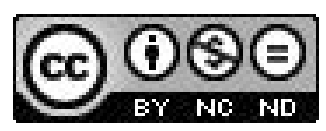

\begin{abstract}
The paper analyses two concepts of art history textbooks for secondary schools. It discusses their role in the learning and teaching process of art history and related school subjects within the formal educational programmes in Slovenia and their didactic structure. The comparison between one Slovenian and two Polish textbooks might contribute to better understanding of the present situation regarding art history textbook production in Slovenia, which is a result of several factors: the historical continuity of textbook writing and research in textbook didactics, the current school policy and financial competition on the textbook market. Its intention is also to clarify the idea of didactic transformation of the art history contents from the challenging scientific texts to a form suitable for secondary school students who are textbooks' main target audience.
\end{abstract}

Key words: formal educational system, art history, textbook, didactics

\section{INTRODUCTION}

The course of formal education is basically defined as a process dealing with two parallel and inseparable activities: evolving one's capabilities and at the same time acquainting oneself with known facts and theoretical as well as practical achievements of different disciplines. The transfer of knowledge, old as the mankind itself, can now occur through several media: language, images and practical occupation but also with the help of different, traditional and modern information carriers, such as paper, audio and video records. Their use and impact depend on our senses, which are the primal receptors of outer reality. Still, we can claim that in the last five hundred years, the written word has dominated as a fundamental and prevalent manner of preserving and transmitting human ideas (Strmčnik, 1975, p. 257). In the era of the so called "Gutenberg galaxy" (cf. Kovač \& Kovač Šebart 2004, pp. 8-9 ${ }^{1}$, books have always represented a prevailing source of knowledge, the role they did not hand over to digital technology and new visual media.

For the influence of print media over the European culture in general see McLuhan (1962). 
From this perspective, textbooks have represented the most common learning tool in the past few centuries and in the present, as they, for their use in everyday school education routine, are able to reach the widest circle of readers. Therefore, it does matter which information they include, how the information is presented, and to what extent it is transmitted.

The paper discusses the position of art history textbooks for secondary schools in Slovenia as a result of the past and present social situations. It also analyses, through its comparison with two Polish art history schoolbooks, the only Slovenian art history textbook that is officially certificated and currently in use. According to that the aim is to outline the circumstances of writing and publishing art history textbooks to open some new perspectives for the further development of art history study material in order to consolidate art history as a school subject. The objectives are to find similarities and differences on the question of the authorship, content, didactic structure which includes content framework and the course of individual didactic phases and the specific circumstances on the two different textbook markets. Due to author's unfamiliarity with the Polish language, the comparison of the linguistic difficulty levels or styles will be left out of the discussion.

\section{THE TEXTBOOK AS THE MAIN TEACHING AID IN THE COURSE OF FORMAL EDUCATION AND ITS OTHER ROLES}

The appearance and development of books, designed particularly for the course of school learning and teaching (Malić, 1992, p. 34), can be observed through the parallel evolution of didactic theories in general (cf. Poljak, 1983, p. 52) and specific scientific fields that intersect in their common subset, the area of formal education. At first, the role of information bases as main sources of knowledge for school lessons was given to books without any significant adaptations (Malić, 1992, p. 33), until the mid-20 $0^{\text {th }}$ century also often imbued with religious doctrine (Johnsen, 1993, p. 13). Medieval manuscripts were gradually substituted by printed textbooks (Ciperle, \& Vovko, 1987, p. 20, as cited in Okoliš, 2009, p. 22). With the development of pedagogical sciences, we can also detect a formation of the new, modern concept of a schoolbook, which was introduced in the middle of the $17^{\text {th }}$ century by Jan Amos Komenský in Didactica Magna (Malić, 1992, p. 33). With his Orbis Sensualium Pictus we received the first illustrated textbook that influenced significantly subsequent concepts of schoolbooks (Johnsen, 1993, p. 35). They became an indispensable tool for teaching and learning for all formal and partly even informal educational programmes ever since.

From the didactic point of view, "textbooks are textual learning media, which as a part of educational technology help to intensify the effectiveness of teaching and self-directed learning" (Kovač, \& Kovač Šebart, 2005, p. 20)². Within the mass of all written sources of knowledge, they are among the less demanding works in terms of their content difficulty level, as they tend to be written for a relatively wide circle of the reading public of a specific age. They function as direct transmit-

For other definitions of textbook, see Skela (2008, pp. 2-4). 
ters of scientific discourses to a form which is appropriate for their users, regarding the science and level of learning. With a specific process of their formation it is more likely to avoid inappropriate simplification happening otherwise due to the successive re-interpretation of original texts.

Due to their role as the main textual media in the educational process, textbooks should be in the centre of attention of researches from all scientific disciplines that have a permanent presence within the formal educational system. From the perspective of academic and scientific research, their constant and didactically consistent use can be considered as an important mechanism to ensure preciseness as well as reliability of the information and relevant theories. Textbooks must be composed according to the reader's age, previous knowledge and experience as well as the level of educational programme. More than this - textbooks simultaneously or intentionally create a representative image of the scientific discipline which is the first and the basic one that young people come in contact with. Therefore, they are of crucial importance for cultivating a profound and intrinsically motivated interest for a certain school subject. In other words, they can help to nurture the curiosity for the particular scientific field or suffocate it completely. At the same time they represent an exhaustive material for research regarding history of teaching and learning (Skela, 2008, p. 2), answer questions regarding the development of scientific fields within school subjects (Johnsen, 1993, p. 48) and their wider social status (cf. Kovač, \& Kovač Šebart, 2003, p. 64; Pingel, 2010, p. 7).

\section{THE ART-HISTORY TEXTBOOKS IN SLOVENIA AND THEIR DEVELOPMENT}

The history of textbook research - in its most general terms - can be traced back to the end of the First World War (Pingel, 2010, p. 9; cf. Johnsen, 1993, p. 21) but soon after the Second World War, the new audio-visual media started to develop rapidly at the time, becoming the centre of attention (Pingel, 2010, p. 9; cf. Johnsen, 1993, p. 21). In the last few decades, the textbook is once again considered the central teaching aid that links together all other more or less technologically advanced learning sources. This idea has given a fresh impetus to the recent research of schoolbooks produced according to the newest didactic knowledge, including international comparative research and research into textbooks' interdisciplinary aspects ${ }^{3}$.

Although there has been a long and rich discussion on the international stage, there is a somewhat different picture of textbook research history in Slovenia, which was formed as a result of political and historical circumstances. Between 1945 and 1991, Slovenia was a part of the Socialist Federal Republic of Yugoslavia.

"With these principles as a basis, international textbook revision has developed into a scientific discipline called textbook research. Its aim is to provide better insights into the interrelationships that exist between the teaching of history, geography and civics and the prejudices and misconceptions in pupils' everyday experiences as conveyed by the general political culture, to which mass media makes an increasing contribution. Thus, textbook research has developed into an interdisciplinary activity, in which historians, geographers, social scientists and educationalists participate in equal measure" (Pingel, 2010, p. 43).For a more detailed review of international textbook research, see Johnsen (1993) and Pingel (2010, pp. 43-46). 
Therefore, almost the entire first decade after the Second World War, until Slovenia's severing of contacts with the Soviet Union, textbooks were simply translated from the Russian language with few adaptations for the Slovenian editions (Malić, 1986, p. 44). After that, it took quite some time to finally diverge from the Soviet pedagogy and to form an own educational system based on proper theoretical grounds (Malić, 1986, pp. 44-46). Yet in the beginning of 1980s, Croatian educationalist Vladimir Poljak expressed regret about the lack of theoretical expertise and actual didactical modification of textbooks in Yugoslavia ${ }^{4}$. The blind spot of the pedagogy and didactics has not disappeared for at least two more decades, as in 2005 Miha Kovač and Mojca Kovač Šebart yet again claimed that in Slovenia textbooks still represent an unexplored field, without any interest among the experts to change this situation (Kovač, \& Kovač Šebart, 2005, p. 11). Nevertheless, some changes have been noticed most recently, presumably owing to appearance and production of the e-textbook which caused the necessity to re-evaluate printed school books and compare them with their digital versions ${ }^{5}$.

As art history as a school subject itself is poorly represented within the Slovenian formal educational programmes for primary and secondary schools and the textbook market comprises a very moderate circle of the reading public, only a few art history textbooks in Slovenian language came into existence ${ }^{6}$. Due to this fact, neither are there any reviews or analyses of art history textbook material, without which it is nearly impossible to issue relevant and helpful guidelines for high-grade didactical forming of new textbooks. Then and now they represent an existing necessity for the further consolidation of art history as a scientific discipline and its development in the Slovenian environment.

Since in the recent decades visual and communication technology have increasingly entered into educational programmes at all levels and fields of study, also the subjects related to art history can no longer be taught in the same conventional way. The far greater accessibility of high-quality art work reproductions has expanded the possibilities of their use and thus altered not only the course of teaching and learning but has also modified pupils' attitude towards the meaning of artworks and the idea of art itself. At the same time, due to the rapid emergence of inter-media art disciplines, textbook chapters on contemporary art practices and modern art have to show artworks, the reproductions of which cannot be simply printed out on a piece of paper but demand other forms of presentation. Traditional verbal descriptions and explanations in textbooks can no longer suitably present these artworks. Owing to the fact that preparing a new textbook material is a time-consuming process that

4 "It is a surprising finding that there are no scientific studies regarding textbooks, nor texts about their didactical modification. [...] Unfortunately we have to conclude that there has been little discussion about didactical modification of textbooks in the post-war period" (Poljak, 1983, p. 13-14).

5 For the latest contribution to textbook and e-textbook research, see Skela (2008) and Kreuh, N., Kač, L., \& Mohorčič, G. (2011).

$6 \quad$ While examining the condition of art history and evaluating its position within the secondary schools in Slovenia, in 1997 Nataša Golob pointed out the lack of textbook material (1997, p. 299). Moreover, in a Slovenian edition of the publication Arts and Cultural Education at School in Europe (Plevnik, T. (ed.), 2010, p. 57) the term textbook is only mentioned once and even in this case merely incidentally. Hence it follows that textbooks as significant sources of knowledge and guidance tools of the teaching process within the art history field remained overlooked. 
can extend even to five years or more (Pingel, 2010, p. 36), the current situation of art history textbook production in Slovenia is more than worrying.

\section{DEFINING THE CIRCUMSTANCES OF TEXTBOOK PRODUCTION IN SLOVENIA AND POLAND}

The comparison between one Slovenian and two Polish textbooks is far from coincidental but is based on the fact that these countries pretty much share a similar political and social history background regarding the second half of the $20^{\text {th }}$ century. At the same time, they differ considerably in size of the textbook market that is influenced by school policy and the number of potential readers, in our case secondary school students.

Both Slovenia and Poland belong to those Central European post-communist countries that had to pass a transition from one social system to another. Since the textbook market is directly dependent on the formal educational system, which is always a reflection of the government's vision, those changes have left significant traces on the production and distribution of schoolbooks.

In the former communist regime, the textbook market functioned according to the principle of one textbook for each school subject. There was no competition among publishers as all school books were produced under the roof of stateowned publishing houses (Kovač, \& Kovač Šebart, 2005, p. 79; cf. Kovač, \& Kovač Šebart, 2004, pp. 13-14). After the transition to democratic capitalism, competition was most swiftly introduced in countries that were able to adapt the existing publishing network to new circumstances by privatizing former public publishing houses that had to confront the competition in the form of new private publishers (Kovač, \& Kovač Šebart, 2005, p. 80). According to Miha Kovač and Mojca Kovač Šebart, this group includes all countries that joined the European Union in 2004 (Kovač, \& Kovač Šebart, 2005, p. 80), among them also Slovenia and Poland. At the turn of the millennia, the publishing of textbooks has been taken over by private publishing houses in all post-communist countries, which at the time caused several problems, especially in some of the former Soviet Republics (Kovač, \& Kovač Šebart, 2005, pp. 80, 86). However, this change was beneficial after all, as it simplified the editorial and publishing process by avoiding a great amount of administrative steps. This resulted in faster publishing, with lower costs. Another resemblance between the two school systems lies in the fact that both of them practice official textbook approval in order to avoid mass printing of low-quality school books (Kovač, \& Kovač Šebart, 2005, pp. 96-98).

On the other hand, Slovenian and Polish textbook markets differ in many ways. With the total of 6,878,237 pupils (statistics from 2002) (Education in Poland Statistics, 2002), enrolled in primary or secondary level of formal educational programmes, Poland has a significantly bigger audience than Slovenia, where the number of 304,672 pupils in 2002 was more than 22-times lower (Slovenian Education facts and figures, 2002).

The size of the market has a great influence not only on retail prices of textbooks, but also on the quality in terms of technical equipment and content. As the 
setup of a printing machine is relatively more expensive than printing itself, lower retail price is much more expected on larger textbook markets (Kovač, \& Kovač Šebart, 2005, pp. 82-83). In an effort to lower the prices for school books, Slovenia has established a mechanism of the state textbook fund (Navodila za upravljanje učbeniških skladov [The directions for handling of the state textbook fund]), by which textbooks are bought by the school and then lent to their users. In this regard, Poland went another step forward with the "Digital School" programme which aims to enable free digital textbooks, approved by the Polish government (Śliwowski, \& Grodecka, 2013) ${ }^{7}$. This project has only resulted in one ministry approved free e-textbook so far (Lorek \& Wollman, 2014).

Finally, the quality of textbooks in general contributes also to the efficiency of the formal educational system. In this regard, Polish elementary and secondary school students, who in the Program for International Student Assessment (PISA) were in the average of OECD countries until 2006, reached even better, aboveaverage results, in 2012 (Polish Student performance: PISA 2012). Compared with Slovenian students of the same education-level (Slovenia Student performance: 2012), they have shown greater competency in all three categories: performance in reading, mathematics and science literacy (table 1). Polish school books can therefore represent a good example for Slovenian textbook writers.

Table 1. The results of PISA 2012 in Slovenia and Poland

\begin{tabular}{|c|c|c|c|c|c|c|}
\hline $\begin{array}{c}\text { 15-year } \\
\text { old } \\
\text { students }\end{array}$ & \multicolumn{2}{|c|}{$\begin{array}{l}\text { performance in } \\
\text { reading (points) }\end{array}$} & \multicolumn{2}{|c|}{ mathematics (points) } & \multicolumn{2}{|c|}{$\begin{array}{l}\text { science literacy } \\
\text { (points) }\end{array}$} \\
\hline Slovenia & 481 & OECD average: & 501 & OECD average: & 514 & OECD \\
\hline Poland & 518 & 496 & 518 & 494 & 526 & average: 501 \\
\hline
\end{tabular}

Source: PISA 2012. Official website of OECD. Retrieved January 16, 2014 from: http:/ / www.oecd.org/

\section{THE COMPARISON OF THE SLOVENIAN AND POLISH ART HISTORY TEXTBOOKS FROM THE SLOVENIAN POINT OF VIEW}

The following chapter deals with the concrete comparison of the Slovenian and the two Polish textbooks. It begins with the aspect of authorship, where some analyses about the professional background and the question of working by oneself/ collaborating are made. Further comparisons deal with the didactic structure of the discussed schoolbooks: the general organisation of the content and the presence of individual didactic phases that round up the learning cycle.

\section{AUTHORSHIP}

In the last fifty years, only two Slovenian officially certificated art history textbooks for secondary schools have been published: Janez Höfler's Basics of the Fine Arts (Osnove likovne umetnosti, first edition in 1977) and Nataša Golob's Art History

\footnotetext{
For more information about the »Cyfrowa Szkoła $[»$ Digital School«] programme, see: Śliwowski, \& Grodecka (2013).
} 
(Umetnostna zgodovina, first edition in 2003), among which the latter is still being regularly used in the teaching process and is therefore most suitable for didactic analysis. For analysis the 2010 edition was used. Polish high school students have a better selection of printed art history textbooks, so we have deliberately focused on Jolanta Gumula's In this Whole Art (W tym cata sztuka, edition from 2009) and Beata Marcinkowska \& Lidia Frydzińska-Światczak's The Land of Art (Kraina sztuki, edition from 2010).

We can see significant differences in terms of the authorship. Both of the Slovenian writers are academics ${ }^{8}$, while authors of selected Polish textbooks, with the exception of Beata Marcinkowska, come from the ranks of those involved in the teaching processes within the lower levels of formal education and museum pedagogy. They have the advantage of direct contact with the age group of pupils and students that are also the target audience of all discussed textbooks. The professional background of the authors could be coincidental but according to Miha Kovač and Mojca Kovač Šebart (2005, pp. 96-97, cf. Kovač, \& Kovač Šebart, 2004, pp. 22-23), there is a significant correlation between textbook authors' position in educational hierarchy and the level of established democratic principles in the country in question. Socialism promoted the idea of the one and only truth regarding basic social and political issues and argued a single path towards it. It is obvious that no one is more competent to chart that course than university professors (Kovač, \& Kovač Šebart, 2005, p. 96). On the other hand, the western democracy has allowed various mindsets and consequently multiple ways of accomplishing learning aspirations, so textbooks could be written by experts who deal with the transmission of knowledge to this particular audience on a daily basis (Kovač, \& Kovač Šebart, 2005, p. 96).

It is difficult to say why Slovenian primary and secondary art history school teachers lack the motivation to write textbooks but this situation is certainly related to the fact that the textbook publishing market in Slovenia does not stimulate the multiplicity of art history school books, since the circle of readers is too small to ensure financial success to publishing houses. In such case, the choice of authors with academic careers is more likely a consequence of the described situation: if there is enough space for only a few coexisting textbooks on the market, their authors should be carefully selected. From this point of view, the academic degree functions as a quality assurance.

The problem of the future authorship of art history schoolbooks in Slovenia can be solved by establishing a team of several writers. Such a team would more easily guarantee the objectivity and scientific credibility and could at the same time provoke interdisciplinary collaboration among various branches within the art history field, such as didactics, iconography, archaeology, contemporary art practices, conservation and restoration, etc.

\footnotetext{
In the case of textbook by N. Golob, it is necessary to add that according to the author, she was all the time confronted by corrections, expressed by two prominent professors from secondary schools, i.e. Alenka Puschner and Olga Paulič; the text was - prior the publication in 2003 discussed and acclaimed by group of some 40 teachers in various Slovenian secondary schools.
} 


\section{BUILDING A CONTENT FRAMEWORK}

The organisation of a textbook structure should primarily follow the curriculum, which is a macro-articulation of the learning content while the textbook is its micro-articulation (Skela, 2008, p. 1; cf. Kovač, \& Kovač Šebart, 2005, p. 25). Due to its historical characterization, art history is prone to linear chronological review of art periods, styles and phenomena. Each chapter usually consists of explanations of the basic terms, followed by a description of the historical background, an explanation of the characteristics of architecture, sculpture and painting and concludes with the analyses of several crucial art works. The sections regarding Greek and Roman Antiquity, Middle Ages, Renaissance, Baroque etc. are introduced by a preliminary chapter which deals with the definition of Visual and Fine Arts, clarifies the elementary terminology and sets the basic classification.

Because the paradigm of school lessons recently tends to turn from the transmission model towards the cognitive-constructivist model of knowledge transfer (cf. Strmčnik, 2010, pp. 65-76), and from the asymmetric towards symmetric communication (Strmčnik, 2001, pp. 111-112), the traditional successive content structure is legitimately called into question. Comprehension of the entire art history timeline demands absorbing a great number of facts, which are useless without a presentation in a wider context. If the teacher (or a student studying individually) tends to do that for each art period, style or artist, he runs out of time, so he is forced to omit an in-depth discussion in order to keep the volume still manageable (cf. Kovač \& Kovač Šebart, 2005, pp. 23-26).

The other possibility is to divide the learning content to autonomous conceptual cores, by which we can eliminate the information ballast and focus on the true understanding as a shift from the concrete to abstract level of comprehension (cf. Kovač \& Kovač Šebart, 2005, pp. 23-26).

Despite crucial changes on the didactic aspect, all discussed textbooks basically still hold to the chronological manner of teaching and learning. In the case of the Slovenian Nataša Golob's textbook, the reason lies in the fact that it has been designed for several different educational programmes that significantly differ in duration and difficulty. Not all of them have the curricula that allow reduction of the content to a few focal points, so the textbook has to follow a prescribed linear chronological layout. Without any doubt, textbooks designed for specific needs and demands of a particular educational programme and its curriculum would make the decision between a chronological and thematic layout much easier.

Due to a very similar format and font, we can compare the volume of textbooks by the number of pages. N. Golob's textbook is the most extensive one, but has the most proportionate content structure. B. Marcinkowska \& L. Frydzinska-Świątczak's textbook is slightly thinner, but lacks introductory chapters dealing with the general art historical terminology. Considering the psychological effect and the didactic tendency to reduce the data-ballast, the most appropriate would be J. Gumula's schoolbook, which is also the shortest. Unfortunately, this quality relates to unavoidable structural simplifications, since there is no additional didactic material and no space for widening or deepening of knowledge, derived from the 
core text, or critical discussion. Then again, the discussed textbook is designed for the first three grades of lower secondary school (approximate age 14-16) and $\mathrm{N}$. Golob's book is, due to the prescription by Ministry for Education, aimed at several study programmes, among them for students in the fourth grade of Slovenian gymnasium (approximate age 18) ${ }^{9}$.

Table 2: The comparison of a content structure

\begin{tabular}{|c|c|c|c|c|c|}
\hline \multirow{2}{*}{$\begin{array}{l}\text { Textbooks } \\
\text { (by au- } \\
\text { thors) }\end{array}$} & \multirow{2}{*}{$\begin{array}{c}\text { Average num- } \\
\text { ber of repro- } \\
\text { ductions per } \\
\text { page (without } \\
\text { timelines) }\end{array}$} & \multicolumn{4}{|c|}{ Number of pages } \\
\hline & & $\begin{array}{l}\text { Introducto- } \\
\text { ry chapters }\end{array}$ & $\begin{array}{l}\text { The sequence } \\
\text { of Art Periods }\end{array}$ & $\begin{array}{l}\text { Additional } \\
\text { chapters }\end{array}$ & Total \\
\hline Golob & 1,3 & $66(31 \%)$ & $93(43 \%)$ & $\begin{array}{l}14(7 \%) \text { : } \\
\text { timelines, } \\
\text { indexes, ref- } \\
\text { erences and } \\
\text { additional } \\
\text { literature }\end{array}$ & 215 \\
\hline Gumula & 2,3 & $31(24 \%)$ & $64(50 \%)$ & $\begin{array}{l}\text { (0\%): extra } \\
\text { material } \\
\text { (timeline), } \\
\text { workbook }\end{array}$ & 128 \\
\hline $\begin{array}{l}\text { Mar- } \\
\text { cinkowska } \\
\text { \& } \\
\text { Frydzińska- } \\
\text { Świątczak }\end{array}$ & 2,0 & $2(1 \%)$ & $182(89 \%)$ & $\begin{array}{l}12(6 \%): \\
\text { vocabulary, } \\
\text { maps, work- } \\
\text { book }\end{array}$ & 204 \\
\hline
\end{tabular}

Source: Golob, 2010, Gumula, 2009, Marcinkowska \& Frydzińska-Świątczak, 2010.

The informative and transformative value of a textbook is significantly determined also by illustrations and other graphic supplements that at the same time evoke emotional charge towards the learning content (Malić, 1986, p. 92 and Malić, 1992, pp. 38-39, cf. Poljak, 1983, p. 54) ${ }^{10}$. The nature of art history itself calls for the need of large and numerous artwork images that represent the primary learning source, and the texts become useless without them. This leads to larger formats and calls for paper of higher quality but consequently causes a higher price and a heavier satchel (cf. Poljak, 1983, p. 54, as cited in: Malić, 1992, p. 39).

A simple calculation shows that both of the Polish textbooks in average contain at least two reproductions of art works per page which is noticeably more than the Slovenian one with an average of only 1,3 images. In addition to that, the images in the Slovenian schoolbook are somewhat smaller. The retail prices of textbooks also differ significantly. While in Slovenia the students have to pay $€ 16.90$ for the textbook (unless they borrow it from a textbook fund), the discussed Polish text-

\footnotetext{
$9 \quad$ This textbook followed the prescription of fulfilling the necessity for art-history courses in general and classical gymnasium as well as technical schools (various professional types) on secondary level.

10 For graphic design of textbooks see: Poljak (1983, pp. 53-71) and Malić (1986, pp. 91-106).
} 
books are provided at a reasonable prices which vary from $14.90 \mathrm{zł}(€ 3.50)$ to 30,88 zł (€7.40), not to mention the newest free e-extbook for elementary schools (Lorek \& Wollman, 2014).

\section{THE ANALYSIS OF DIDACTIC PHASES WITHIN THE INDIVIDUAL CHAPTERS}

Almost all experts dealing with the theory of didactic creation and modification of textbook material emphasize the importance of incorporation of all didactic phases that constitute the educational course, or at least of their specific elements: the introduction of a new topic, the discussion, the training and repetition and finally the examination and grading of knowledge (cf. Strmčnik, 1975, 5/6, pp. 181-187; Poljak, 1983, p. 22; Milekšić, 1992, p. 29; Malić, 1986, p. 71). The cycle of these phases can be performed at varying pace and on different degrees of interweaving (Poljak, 1983, pp. 31-32). In the following captions, we will try to determine the presence, extent and forms of inclusion of each didactic phase in their natural sequence of progression.

Every chapter usually begins with The Introduction, which has three main purposes: it tests previous knowledge of the current topic, introduces the content and learning objectives, and motivates. At this point, teachers mostly use some other teaching aids rather than the textbook itself, as they are acquainted with the students' learning habits and personalities as well as the curricula of other school subjects. Some short teacher's questions or tasks utterly suffice to get an approximate image of the previous knowledge but we cannot forget that a textbook is also used as the main aid for individual study at home (cf. Kovač, \& Kovač Šebart, 2005, p. 20). For that reason, the textbook should contain questions, tasks, exercises or/and directives for activities, designed for the revision of the knowledge that is a prerequisite for further study. J. Gumula's and B. Marcinkowska \& L. Frydzińska-Świątczak's textbooks do not include any such elements, while N. Golob, in a form of short questions or tasks on the outer margin, explicitly directs readers to revise their knowledge from other subjects, especially history, literature and general knowledge ${ }^{11}$.

The motivational aspect that establishes and maintains student's interest for a particular topic, can be expressed in a form of short facts that are surprising, astonishing or even controversial and consequently raise his attention in a very short time: notes in the sense of "did you know," short anecdotes from artists' lives or picturesque descriptions of historical events. We can find this kind of information in all of the discussed textbooks and they complement the core text on almost every page. N. Gumula titles these boxes with "Did you know?", B. Marcinkowska \& L. Frydzińska-Świątczak with "Interesting", while N. Golob uses no explicit title but indicates the nature of this content by graphical means.

The discussion of new topics is the core phase of learning and teaching and by that also represents the majority of the textbook content. Beside logical, transparent and

11 The chapter Aegean Art, for example, includes the task: "Revise your knowledge about literature: in which of the Greek epic poems can you find Agamemnon and who else had fought by his side in front of the Trojan walls?" (Golob, 2010, p. 82). 
evident systematization of particulars that lead to more abstract generalizations (Poljak, 1983, pp. 24-25) ${ }^{12}$, it is also crucial to consider the basic principles of an inner differentiation and individualization (cf. Kalin, 2006, p. 79) ${ }^{13}$. The content and didactic differentiation is obtained by structuring the text into chapters, different levels of subchapters and paragraphs in all three textbooks. According to the judgement of a teacher, they can function as basic study material or additional texts that expand as well as deepen the basic knowledge (cf. Kalin, 2006, pp. 81-82).

Especially the most demanding topics call for more than one presentation or explanation, written from different points of view but volume limitations make that effort impossible for each individual topic. Polish authors tend to solve this problem by rich illustrative material, in a sense that a multitude of art pieces speaks for itself and offers different aspects of a discussed art period. N. Golob goes a step further and adds written analyses of individual works of art, where these aspects are also clearly articulated by putting them into a wider social context.

The following didactic phases correspond to the stage of the learning period at which the student has already become familiar with the topic and wishes to revise, consolidate and examine his knowledge. The repetition of facts is incorporated in the entire text by writing the most important words (terms, names etc.) in bold font in all of the discussed textbooks. In B. Marcinkowska \& L. Frydzińska-Świątczak's textbook, each chapter is followed by a subchapter, entitled Issues from the world of art with a short summary and the key facts. There are also questions and tasks for individual study, some suggestions for creative activities in the classroom and at the end a terminological vocabulary. The other two textbooks confine to several less didactic items: J. Gumula uses comprehension questions and a general timeline of all Art Periods, while N. Golob provides a mind map of the discussed topic and, at the end of the textbook, timelines and additional literature.

\section{CONCLUSIONS AND PERSPECTIVES}

The current situation of art history in Slovenia regarding its position in the formal educational system confronts the rapid enforcement of the new visual media and communication technology. That clearly asserts the need for new didactic material, especially textbooks that would reconsider the priorities in the transmission of the learning contents by taking into account the latest didactic theories and the constantly changing educational role of art history as a school subject.

The comparison of two Polish art history textbooks with the Slovenian one shows some important differences which correlate with the size of textbook markets in these two countries. Firstly, the Polish teachers, compared to their Slovenian colleges, have more options in adapting the learning sources to their own autonomous way of teaching on account of the greater variety of selection of schoolbooks that are also far more affordable or even freely accessible online. They include a higher number of artworks, reproduced in larger formats, which ensures

12 The decomposition of text to smaller and smaller parts follows the didactic concept of short learning steps (Strmčnik, 1975, 5/6, p. 185).

13 For the discussion on different types of differentiation, see Strmčnik (1999) and Kalin (2006). 
reliable visual information. Accompanying workbooks containing various exercises, extend the possibilities of different didactic approaches, inner-differentiation and individualisation of the learning process. At the same time, they are specifically designed for one educational programme and so their content is more easily adapted to the age and capability of the particular students.

On the other hand, the Slovenian textbook is the most extensive one and its proportion of text to images goes in favour of written explanations. In regard to chronological approach, it offers a balanced content structure, as a great part of the volume establishes key concepts and classifies visual arts in general. It also offers additional texts in a form of individual artwork analyses. They not only support the explanation in the main text but also incorporate new, sometimes even different aspects on the discussed topic, which is highly necessary for the shift from the concrete to the abstract level of understanding. While it does have some useful extra materials, such as mind maps and timelines, it unfortunately lacks some additional exercises, which would be especially welcome due to the absence of an accompanying workbook.

In line with these findings, the future Slovenian art history textbooks should be written for one particular educational programme, which would enable the reduction of the main text and make space for larger artwork reproductions and the rest of the didactic apparatus, such as questions, short tasks, exercises and propositions for activities in the classroom. Designing an additional workbook would be an even better option.

All these requests confront the situation on the Slovenian textbook market that does not provide enough space for more than one art history textbook, let alone for serious competition. In order to approach the Polish textbook writing and publishing strategy, the proper school politics in Slovenia would have to compensate the deficiency of the market and ensure a wider selection of schoolbooks. In this case, the authors could focus on one specific circle of the target audience and more successfully meet the didactic objectives, set in the school subjects' curricula.

\section{ACKNOWLEDGEMENTS}

I would like to express my very great appreciation to my mentor, Professor Nataša Golob, for her patient guidance, enthusiastic encouragement and useful critiques of this research work.

\section{SOURCES}

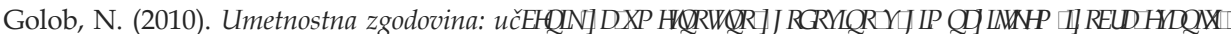

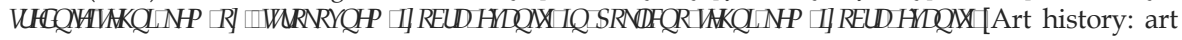
history textbook for the gymnasium and other secondary technical and vocational programmes]. Ljubljana: DZS.

Gumula, J. (2009). W tym cała sztuka: Podręcznik do plastyki - gimnazjum [In this Whole Art: Textbook for arts for gymnasium]. Kielce: Grupa Edukacyjna.

Lorek, M. \& Wollman, L. (2014). Nasz elementarz: Podręcznik do szkoty podstawowej, klasa 1, część 1. [Our Primer: Textbook for primary schools, Class 1, Part 1]. Warszawa: Ministerstwo Edukacji Narodowej/Centrum Informatyczne Edukacji. Retrieved from: http:/ / www.naszelementarz.men.gov. $\mathrm{pl} /$ elementarz/dzieci.html 
Marcinkowska, B. \& Frydzińska-Świątczak, L. (2010). Kraina Sztuki: Podręcznik do plastyki dla gimnazjum [The Land of Art: Textbook for the Arts - gymnasium]. Warszawa- Łódz: Wydawnictwo szkolne PWN.

\section{REFERENCES}

Ciperle, J., \& Vovko, A. (1987). Šolstvo na Slovenskem skozi stoletja [Schools in Slovenia over the Centuries]. Ljubljana: Slovenski šolski muzej.

Education in Poland Statistics (2002). UNESCO Institute for Statistics. Retrieved from: www.nationmaster.com.

Golob, N. (1997). Umetnostna zgodovina v slovenskem srednjem šolstvu ali variacije znanega baladnega motiva [Art history in Slovenian secondary education as the variation of the well-known ballade motif]. Zbornik za umetnostno zgodovino 33 (nova vrsta), 299-303.

Höfler, J. (1977). Umetnostna vzgoja: osnove likovne umetnosti [Art Education: Basics of the Visual Arts]. Ljubljana: DZS.

Johnsen, E. B. (1993). Textbooks in the Caleidoscope: A Critical Survey of Literature and Research on Educational Texts. Oslo: Scandinavian University Press.

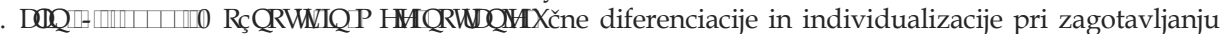

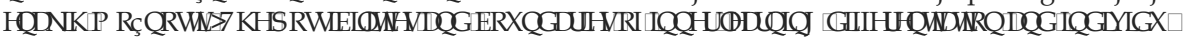
alisation for maintaining equal chances]. Sodobna pedagogika, 57, 78-93.

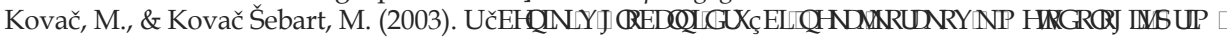
erjalnega raziskovanja [Textbooks in a global society: a few steps towards the methodology of comparative research]. . QKQTHD $\mid 1\|1\| 1141-68$.

Kovač, M., \& Kovač Šebart, M. (2004). Učbeniki v postsocialističQIK Gழ̧̧DYK QDWDYN]DSUP HUWR analizo [Textbooks in post-socialist countries: grounds for comparative analysis]. . QKQRHDWII, 7-31.

Kovač, M., \& Kovač Šebart, M. (2005). UčEHQILIQQX EDznanja [Textbooks and the Society of Knowledge]. Ljubljana: Pedagoška fakulteta: Center za študij edukacijskih strategij, Znanstveni inštitut Filozofske fakultete.

Kreuh, N., Kač, L., \& Mohorčič, G. (2011). Izhodišča za izdelavo e-učbenikov [The directives for designing e-textbooks]. Ljubljana: Zavod RS za šolstvo. Retrieved from http://www.zrss.si/pdf/izhodiscee-ucbeniki.pdf

Plevnik, T. (ed.). (2010). Kulturno-umetnostna vzgoja v šolah po Evropi [Arts and Cultural Education at School in Europe]. Ljubljana: Ministrstvo za šolstvo in šport RS.

Malić, J. (1986). Koncepcija suvremenog XGçEHQND>7 KHFRQFF\$WR WXHFRQMP SRUU $\backslash$ MM WRRN@Zagreb: Školska knjiga.

Malić, J. (1992). Vloga učbenika pri pouku [Textbook's role in the learning course]. Učbeniki danes in jutri: prispevki s srečanja avtorjev učbenikov DZS, Bled, 11. septembra 1991. Ljubljana: DZS, 33-40.

McLuhan, M. (1962). The Gutenberg Galaxy: The Making of Typographic Man. Toronto: University of Toronto Press.

Milekšić, V. (1992). Učbeniško gradivo v funkciji didaktičnega koncepta [The role of textbook material within the didactic concept]. Učbeniki danes in jutri: prispevki s srečanja avtorjev učbenikov DZS, Bled, 11. septembra 1991. Ljubljana: DZS, 27-31.

Official website of the European Union (2009, June 16). Retrieved from: http:/ / europa.eu

Official website of the Ministry of Education, Science and Sport of the Republic of Slovenia. Retrieved January 15, 2014 from: www.mizs.gov.si

Navodila za upravljanje učbeniških skladov [The directions for handling of the state textbook fund]. Official website of the Ministry of education, Science and Sport of the Republic of Slovenia. Retrieved January 15, 2014, from: http://www.mizs.gov.si/si/delovna_podrocja/ direktorat_za_predsolsko_vzgojo_in_osnovno_solstvo/osnovno_solstvo/ucbeniki/ navodila_za_upravljanje_ucbeniskih_skladov/\#c17877

Okoliš, S. (2009). Zgodovina šolstva na Slovenskem [The History of Schools in Slovenia]. Ljubljana: Slovenski šolski muzej.

Pingel, F. (2010). UNESCO Guidebook on Textbook Research and Textbook Revision. Paris/Braunschweig: United Nations Educational, Scientific and Cultural Organisation \& Georg Eckert Institute for Textbook Research. Retrieved from http://unesdoc.unesco.org/images/0011/001171/117188e. pdf 
PISA 2012. Official website of OECD. Retrieved January 16, 2014 from: http:/ / www.oecd.org/

Plevnik, T. (Ed.) (2010). Kulturno umetnostna vzgoja v šolah po Evropi (trans. Plevnik, P.) [Arts and Cultural Education at School in Europe]. Ljubljana: Ministrstvo RS za šolstvo in šport.

Poland Student performance (PISA 2012). Retrieved January 15, 2014, from: http:// gpseducation.oecd. org/CountryProfile?primaryCountry $=$ POL\&treshold=10\&topic $=P I$

Poljak, V. (1983). Didaktično oblikovanje učbenikov in priročnikov [Didactic formation of textbooks and manuals]. Ljubljana: DZS.

Skela, J. (2008). Smernice za avtorje učbenikov [Directives for textbook authors]. Ljubljana: Center RS

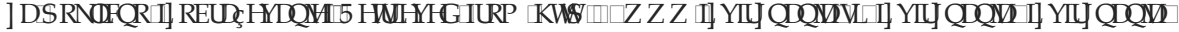
datoteke/5-002_SMERNICE\%20ZA\%20AVTORJE\%20UCBENIKOV.pdf

Slovenia Student performance (PISA 2012). Retrieved January 15, 2014, from: http://gpseducation. oecd.org/CountryProfile?primaryCountry $=S V N \&$ treshold=10\&topic $=P I$

Śliwowski, K., \& Grodecka, K. (2013). Open Educational Resources in Poland: Challenges and Opportunities. Moscow: UNESCO Institute for Information Technologies in Education. Retrieved from: http://iite.unesco.org/pics/publications/en/files/3214727.pdf

Slovenian Education facts and figures (2002). UNESCO Institute for Statistics. Retrieved from: www. nationmaster.com.

Strmčnik, F. (2001). Didaktika: osrednje teoretične teme [Didactics: core theoretical topics]. Ljubljana: Znanstveni inštitut Filozofske fakultete.

Strmčnik, F. (1975). Pedagoška funkcija in zgradba učne knjige [Pedagogical role and structure of a school book]. Sodobna pedagogika, 26(5/6), 177-189.

Strmčnik, F. (1975). Pedagoška funkcija in zgradba učne knjige [Pedagogical role and structure of a school book]. Sodobna pedagogika, 26(7/8), 257-270.

Strmčnik, F. (2010). Problemski pouk v teoriji in praksi [Theory and praxis of the problem-based learning]. Novo mesto: Visokošolsko središče Novo mesto, Inštitut za raziskovalno in razvojno delo.

Strmčnik, F. (1999). Učna diferenciacija bodoče osnovne šole v luči kritike [Learning differentiation in the future primary school from a critical point of view]. Sodobna pedagogika, 50(1), 52-71.

UNESCO Institute for Statistics (2002). Retrieved from: www.nationmaster.com. 